\title{
Splenic calcification in systemic lupus erythematosus
}

\author{
Fatehi E Elzein, Safa Elzein, Rashed Albalawi
}

Department of Medicine, Prince Sultan Military Medical City, Riyadh, Saudi Arabia

\section{Correspondence to Dr Fatehi E Elzein, fatehielzein@gmail.com}

Accepted 7 September 2017

\section{DESCRIPTION}

A 39-year-old woman with known systemic lupus erythematosus (SLE) nephropathy, antiphospholipid syndrome and chronic renal failure was evaluated for renal transplant. She was asymptomatic; nevertheless, the abdominal ultrasonogram showed splenic calcification (figure 1). The chest radiograph showed faint lesions suggestive of (L) hypochondrial calcification (figure 2). The tuberculin skin test result revealed induration of $3 \mathrm{~mm}$. She had no history of treatment for tuberculosis or brucellosis. The angiotensin-converting enzyme was normal at $19 \mathrm{U} / \mathrm{L}$ (normal range 29-112 U/L). A CT scan of the abdomen and pelvis showed a bulky spleen that contained numerous small and differently sized smooth calcific foci probably related to granulomatous disease. No calcification was seen in the liver (figure 3A, B). There were no definite or suspicious pulmonary nodules seen on a whole body fluorodeoxyglucose positron-emission tomography (PET) scan. Similarly, numerous tiny splenic calcifications with no abnormal metabolic activity were detected (figure 4). The haemoglobin level was $11.5 \mathrm{~g} / \mathrm{dL}$, white blood count was $7.1 \times 10^{9} / \mathrm{L}$, platelet count was $244 \times 10^{9} / \mathrm{L}$ and erythrocyte sedimentation rate was $22 \mathrm{~mm} /$ hour. Results of the sickling test, HIV, brucella serology and hydatid and schistosoma serology tests were all negative. She was

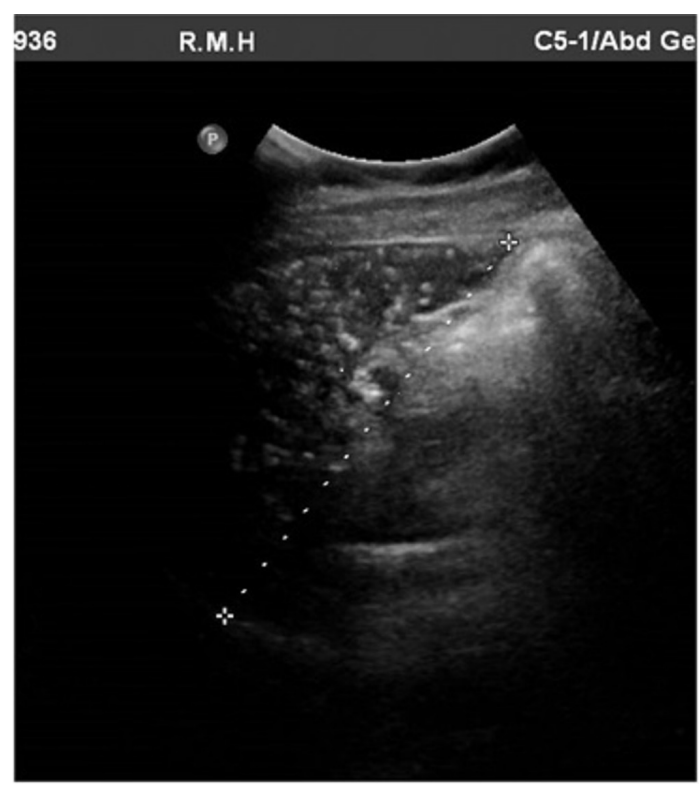

Figure 1 Ultrasound abdomen showing multiple small hyperechoic shadowing throughout the splenic parenchyma.

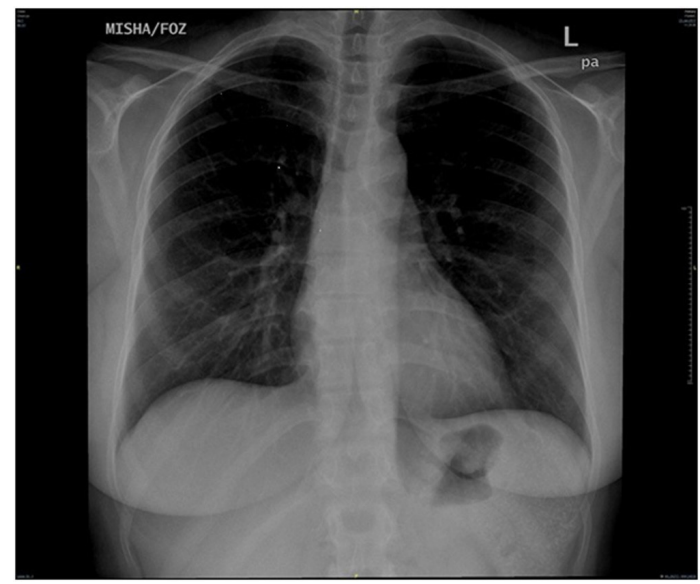

Figure 2 Chest X-ray with faint (L) hypochondrial calcification.

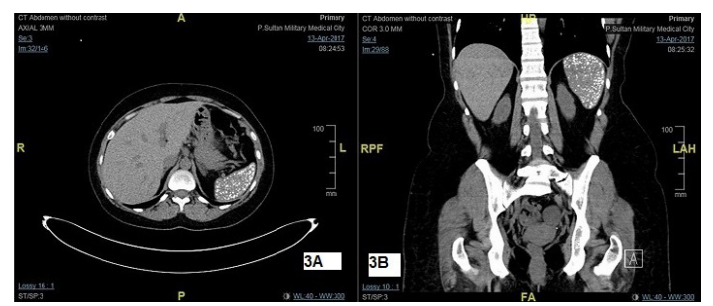

Figure 3 CT scan showing spleen that contains numerous small different size smooth calcific foci.

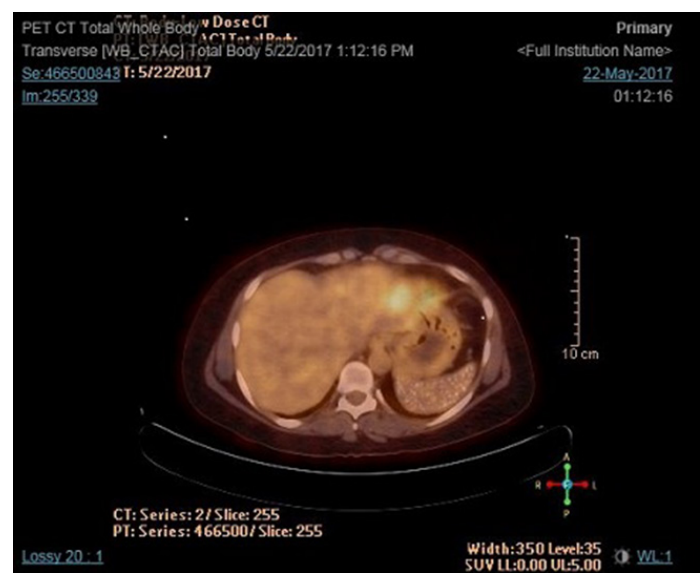

Figure 4 Positron emission tomography scan showing splenic calcification without abnormal metabolic activity.

given a pneumococcal vaccine and is awaiting a deceased donor kidney transplant.

Although splenomegaly is detected in 9\%-18\% of patients with SLE, splenic calcification has been rarely described in such patients. ${ }^{1}$ Splenic calcification may precede autosplenectomy and hyposplenism, emphasising the importance of 


\section{Learning points}

Splenic calcification in systemic lupus erythematosus (SLE) is very rare; the pattern of calcification is distinctive and can imply the diagnosis of SLE.

- The calcification may be associated with hyposplenism, emphasising the importance of pneumococcal vaccination in these patients.

- In endemic areas, granulomatous causes of splenic calcification may need to be excluded.

pneumococcal vaccination in such patients. The pattern of calcification is so distinctive that it could hint at the diagnosis of SLE. There are usually widely distributed small, rounded, calcific lesions scattered throughout the spleen. Conversely, the antiphospholipid syndrome detected in our patient can predispose patients to segmental splenic infarction rather than diffuse calcification. The exact explanation why this calcification occurred only in the spleen is not clear. There are suggestions it could signify calcification in the 'onion-skin nodules' which is regarded as a pathognomonic histopathological feature of SLE. ${ }^{2}$ Brucellosis, tuberculosis and hydatid disease are endemic to this area; although unique numerous, thin, target-like calcifications in the spleen have been described in brucellosis, calcifications in tuberculosis are more widespread and involve the liver and lymph nodes. ${ }^{3}$

Contributors FEE diagnosed the patient condition and followed her up in the clinic, written the manuscript and approved the final version and was fully responsible for the accuracy and integrity of the article. SFE did the literature search and contributed to the writing and revising the manuscript, final approval of the version for publication and agreed to be accountable for the accuracy and integrity of the article. RA, the infectious diseases fellow, was following the patient in the clinic in addition to preparation of the images. He revised and approved the final version of the manuscript and agreed to be accountable for the accuracy and integrity of the article.

Competing interests None declared.

Patient consent Obtained from guardian.

Provenance and peer review Not commissioned; externally peer reviewed.

(C) BMJ Publishing Group Ltd (unless otherwise stated in the text of the article) 2017. All rights reserved. No commercial use is permitted unless otherwise expressly granted.

\section{REFERENCES}

1 Alarcón-Segovia D. Gross splenomegaly in SLE. Arthritis Rheum 1978:21:866-7.

2 Tieng AT, Sadow CA, Hochsztein JG, et al. Diffuse calcifications of the spleen: a novel association with systemic lupus erythematosus. Semin Arthritis Rheum 2011:41:187-93.

3 Torres US, Cardoso LV, D'Ippolito G. A pathognomonic calcification pattern in chronic splenic brucellosis. Braz J Infect Dis 2015;19:664-5.

Copyright 2017 BMJ Publishing Group. All rights reserved. For permission to reuse any of this content visit

http://group.bmj.com/group/rights-licensing/permissions.

BMJ Case Report Fellows may re-use this article for personal use and teaching without any further permission.

Become a Fellow of BMJ Case Reports today and you can:

- Submit as many cases as you like

- Enjoy fast sympathetic peer review and rapid publication of accepted articles

- Access all the published articles

Re-use any of the published material for personal use and teaching without further permission

For information on Institutional Fellowships contact consortiasales@bmjgroup.com

Visit casereports.bmj.com for more articles like this and to become a Fellow 